\title{
The Study of Solid Waste Management to Extend the Lifetime of Sukoharjo Landfill, Pati Regency
}

\author{
Mei Viantikasari ${ }^{1 *}, P$ Purwanto ${ }^{1,2}$, and Mochamad Arief Budihardjo ${ }^{1,3}$ \\ ${ }^{1}$ Master Program in Environmental Science, Diponegoro University, 50275 Semarang, Indonesia \\ ${ }^{2}$ Department of Chemical Engineering, Diponegoro University, 50275 Semarang, Indonesia \\ ${ }^{3}$ Department of Environmental Engineering, Diponegoro University, 50275 Semarang, Indonesia
}

\begin{abstract}
The waste generation increases along with the increase of population and then the percentage of waste services is increasing every year so the capacity of Sukoharjo landfill becomes decreasing. While to find a suitable location for new landfill sites that are completed requirements of regulation is difficult. It is needed some actions to extend the lifetime of Sukoharjo landfill, one of them is application 3R (Reduce, Reuse, Recycle) mechanism in waste management. This study aims to analyze the lifetime of Sukoharjo landfills with the mechanism of Reuse, Reduce and Recycle (3R). The method used in this research is quantitative and qualitative methods. Based on the calculation, the landfill only available until 2022. The existence of composting and recycling of anorganic waste, landfill lifetime will extend until 2025. Our results show that there is a significant comparison of the volume waste in landfills between untreated incoming trash with treated by Reduce, Reuse, Recycle (3R) mechanism. By 2028, the waste generation in a landfill will be $24,821,724 \mathrm{~kg}$. During composting (30\%) and recycling of anorganic waste $(15 \%)$, the volume of waste in landfill is reduced to $14,401,796 \mathrm{~kg}$.
\end{abstract}

Keywords: waste generation; lifetime landfill; 3R mechanism; Sukoharjo landfill.

\section{Introduction}

Increasing the population of Pati Regency every year will be in line with the increase in waste produced. Various innovations in waste management are needed to prevent greater environmental problems due to waste. In 2017 total population of Pati regency was $1,246,691$ people, up $0.54 \%$ from 2016 which is $1,239,989$ people [1]. This was followed by an increase of waste generation volume. In 2016 the waste produced $1,897,183 \mathrm{~L} /$ day and increase to $1,907,437 \mathrm{~L}$ /day in 2017[2]. Increasing the population who are not balanced with the capability to manage waste has potential to cause various complex problems [3].

A landfill is the basic need of a city to dispose their municipal solid waste (MSW). According The Waste Law No. 18/2008, a landfill is an area for processing and returning waste to environmental media safely for humans and the environment. Pati Regency has 3 landfills namely Sukoharjo landfill, Plosojenar landfill and Sampok landfill. According to The Waste Law No. 18/2008 Article 44 that in article 44 clause 1 states that the government have to plan for the closure of landfill using an open dumping system no later than 1 year from the enactment of this Law. After that, in clause 2 states that the Government have to close the final processing site of waste which uses an open dumping system no later than 5 years from the date the enactment of this Waste Management Law [4]. The Sampok landfill and
Plosojenar landfill are planned to close soon because they operate using open dumping so in the future the Sukoharjo landfill becomes the only landfill in Pati Regency. The impact of this condition is an increase in waste entering the landfill.

TPA Sukoharjo who located in Sukoharjo village Margorejo Sub-district Pati regency operated using sanitary landfill. The area of Sukoharjo landfill is about 12.5 ha and began operating since 1994. Currently the Sukoharjo landfill is operated to manage waste from 8 (eight) sub-districts from 21 sub-districts located in Pati Regency. Sukoharjo landfill produces a large quantity of municipal solid waste (MSW) that has increased rapidly: about $13,983.27$ Ton in 2015 and about 18,033.20 Ton in 2017 [2] and it will affected to the landfill lifetime. If the lifetime of the landfill runs out, new land is needed. It is not easy to find the suitable location for a new landfill site that completed requirements of regulation. Sometime there is also resistance of local citizen when a landfill site will be built in their locality [5].

Community-based waste management by synergizing with the waste management system in the landfill is a effective waste management model that can be done in Pati Regency [6]. Landfill lifetime will take much longer with the mechanism of Reuse, Reduce and Recycle (3R) process [7]. To extend the lifetime of the landfill, one solution is to process and recycle waste before being disposed. The reduction of the waste volume through waste recycling (reuse, recycling, recovery), composting

\footnotetext{
* Corresponding author: meichemistry2010@gmail.com
} 
and incineration [8]. Recycling of organic waste through composting process could contribute to environmental impact and the solution of waste management significantly. Recycling could produce compost/ fertilizer product, minimize GHG emissions and extend landfill life [9]. The aim of this study is to analyse the lifetime of Sukoharjo landfill with the mechanism of Reuse, Reduce and Recycle (3R) process.

\section{Method}

This research was conducted at Sukoharjo landfill in Pati Regency. Primary data includes surveys and field observations at the study site and interviews. Secondary data includes population data, waste characteristics data, waste data on weigh bridges, related regulatory data and Sanitation Strategy Book Pati Regency.

Analysis of primary and secondary data is carried out quantitatively and qualitatively. Quantitative analysis carried out on the results of measurement of population projection and waste generation projection using arithmatic methode, and analysis landfill lifetime. While qualitative/descriptive analysis was carried out on things that were not measured, for example the results of interviews and information gathering to waste management agencies.

\section{Result}

Based on the information from Department of Public Works and Spatial Planning Pati Regency, service areas of Sukoharjo landfill cover eight sub-districts in Pati Regency, including Pati, Margorejo, Trangkil, Gembong, Gabus, Winong, Kayen and Wedarijaksa sub-districts with the total population in 2017 is 513,115 people. Not all villages in each sub district dispose of their waste to the Sukoharjo landfill. The waste disposed to Sukoharjo landfill comes mostly from Pati sub-district with a total of 22 Villages because it is located in urban areas. Then Margorejo sub-district is 2 villages, Trangkil sub-district as many as 3 villages, Gabus sub-district as many as 2 villages, and only a village in Gembong, Winong, Kayen and Wedarijaksa sub-districts. So the total of waste service area in Sukoharjo landfill is 33 villages with the total population in 2017 is 170,753 people [1].

Based on BPS data in 2012-2017, it is known that the population growth rate is $0.6 \%$. Projections of total population is calculated using arithmetic method. The waste generation per capita in Pati Regency is 2.13 $\mathrm{L} /$ person/day [10] so projections of waste generation for 10 next years can be determined. Projections of population and waste generation for 10 next years can be seen in table 1 .

Table 1. Projections of total population and waste generation in 2019-2028

\begin{tabular}{|c|c|c|}
\hline Year & $\begin{array}{c}\text { Total } \\
\text { Population } \\
\text { (people) }\end{array}$ & $\begin{array}{c}\text { Waste } \\
\text { Generation } \\
\left(\mathbf{m}^{3}\right)\end{array}$ \\
\hline 2019 & 172,802 & 134,345 \\
\hline
\end{tabular}

\begin{tabular}{|l|l|l|}
\hline 2020 & 173,827 & 135,141 \\
\hline 2021 & 174,851 & 135,938 \\
\hline 2022 & 175,876 & 136,734 \\
\hline 2023 & 176,900 & 137,531 \\
\hline 2024 & 177,925 & 138,328 \\
\hline 2025 & 178,949 & 139,124 \\
\hline 2026 & 179,974 & 139,921 \\
\hline 2027 & 180,998 & 140,717 \\
\hline 2028 & 182,023 & 141,514 \\
\hline
\end{tabular}

Based on SNI 19-3964-1995 about the method of taking and measuring samples of waste generation and the composition of urban waste, waste generation in landfill is determined by measuring/recording directly the amount of waste entering the landfill. Data is obtained from Weigh Bridge from April 1, 2019 to April 30,2019 . The result of the data calculation show that the waste generation processed in Sukoharjo landfill an average of $47,798 \mathrm{~kg} /$ day. Measurements of density waste were carried out by sampling the type of garbage vehicles which weighed on a weighbridge to find out the empty weight of the garbage vehicle and when it was filled with waste. Garbage vehicles that have different types will have different capacities (in volume) so the average density of waste can be known by dividing the weight of waste on garbage vehicles and the capacities of garbage vehicles when full of waste. According to the result of measurements, the average density of waste entering Sukoharjo landfill is $253 \mathrm{~kg} / \mathrm{m}^{3}$ so the total volume of waste generation daily in TPA is 188.92 $\mathrm{m}^{3} /$ day. If the total volume of waste generation daily in 2019 is $368.07 \mathrm{~m}^{3} /$ day so the percentage of waste service to waste that will be managed by landfill is $51.33 \%$.

Based on Sanitation Strategy Book Pati Regency, target of waste service increase by $2 \%$ per year so prediction of waste generation in Sukoharjo Landfill for 10 next years can be shown in table 2 .

Table 2. Waste generation in Sukoharjo Landfill 20192028

\begin{tabular}{|c|c|c|c|c|}
\hline \multirow{2}{*}{ Year } & \multirow{2}{*}{$\begin{array}{c}\text { Waste } \\
\text { Generat } \\
\text { ion }\left(\mathbf{m}^{3}\right)\end{array}$} & \multirow{2}{*}{$\begin{array}{c}\text { Percentag } \\
\text { e of waste } \\
\text { services } \\
(\%)\end{array}$} & \multicolumn{2}{|c|}{$\begin{array}{l}\text { Waste Generation in } \\
\text { Landfill }\left(\mathbf{m}^{3}\right)\end{array}$} \\
\hline & & & Vol. $\left(\mathrm{m}^{3}\right)$ & $\begin{array}{l}\text { Weight } \\
\text { (Kg) }\end{array}$ \\
\hline 2019 & 134,345 & 51.33 & 68,958 & $17,446,270$ \\
\hline 2020 & 135,141 & 53.33 & 72,069 & $18,233,522$ \\
\hline 2021 & 135,938 & 55.33 & 75,213 & $19,028,835$ \\
\hline 2022 & 136,734 & 57.33 & 78,388 & $19,832,209$ \\
\hline 2023 & 137,531 & 59.33 & 81,595 & $20,643,643$ \\
\hline 2024 & 138,328 & 61.33 & 84,835 & $21,463,138$ \\
\hline 2025 & 139,124 & 63.33 & 88,106 & $22,290,693$ \\
\hline 2026 & 139,921 & 65.33 & 91,408 & $23,126,310$ \\
\hline 2027 & 140,717 & 67.33 & 94,743 & $23,969,987$ \\
\hline 2028 & 141,514 & 69.33 & 98,110 & $24,821,724$ \\
\hline
\end{tabular}

Based on table 2, the increase of waste generation and percentage of waste service resulted an increase of 
waste generation in the landfill. In 2019 the waste generation in landfill is $68,958 \mathrm{~m}^{3}$ and increases to $98,110 \mathrm{~m}^{3}$ in 2028 .

The Sukoharjo landfill is operated using sanitary landfill method. The total active area for landfilling in Sukoharjo landfill is 1,67 ha. The Total capacity of active area is $157,230 \mathrm{~m}^{3}$ [10]. According to the field observation the active zone has been used $26,205 \mathrm{~m}^{3}$ so the remaining volume is $131,025 \mathrm{~m}^{3}$.

In the active area of landfill consists of several lift. In a lift there are 3 waste cells separated by a daily layer 15 $\mathrm{cm}$ thick. The height of each waste cell is planned for 1.5 $\mathrm{m}$. For the cover between the lift, use an intermediate layer $30 \mathrm{~cm}$ thick so the total height of a lift along the layer is $5.1 \mathrm{~m}$. Whereas there is also a final cover with a layer of gravel as a gas pathways horizontally $20 \mathrm{~cm}$ thick, a layer of clay with a permeability of $1 \times 10^{-7} \mathrm{~cm} /$ second is $20 \mathrm{~cm}$ thick, a layer of gravel as under drain from rain water is $20 \mathrm{~cm}$ thick, geotextile layer, and finally the topsoil is $60 \mathrm{~cm}$ thick [11]. The overall soil cover application is assumed to be $15 \%$ of the remaining volume so the total remaining capacity for waste in landfill is $111,371.25 \mathrm{~m}^{3}$.

According to Damanhuri (2008) that the density of compacted waste at landfill is $600 \mathrm{~kg} / \mathrm{m}^{3}-800 \mathrm{~kg} / \mathrm{m}^{3}[7]$. In calculating the volume of compacted waste in the Sukoharjo landfill is assumed to $700 \mathrm{Kg} / \mathrm{m}^{3}$. Then the volume of compacted waste can be calculated from 2019 - 2028 and it will be known the lifetime of the landfill when waste is not handled before entering the landfill.

Table 3. Waste generation in Sukoharjo Landfill 20192028 without $3 \mathrm{R}$ mechanism

\begin{tabular}{|c|c|c|c|c|}
\hline \multirow[t]{2}{*}{ Year } & \multicolumn{2}{|c|}{$\begin{array}{c}\text { Waste Generation in } \\
\text { Landfill }\end{array}$} & \multirow{2}{*}{$\begin{array}{c}\text { Volume } \\
\text { of } \\
\text { compacte } \\
\text { d waste } \\
\left(\mathrm{m}^{3}\right) \\
\end{array}$} & \multirow{2}{*}{$\begin{array}{c}\text { Accumula } \\
\text { tion } \\
\text { Volume of } \\
\text { compacted } \\
\text { waste }\left(\mathrm{m}^{3}\right)\end{array}$} \\
\hline & Vol. $\left(\mathrm{m}^{3}\right)$ & Weight (Kg) & & \\
\hline 2019 & 68,958 & $17,446,270$ & $24,923.39$ & $24,923.39$ \\
\hline 2020 & 72,069 & $18,233,522$ & $26,047.80$ & $50,971.19$ \\
\hline 2021 & 75,213 & $19,028,835$ & $27,184.13$ & $78,155.31$ \\
\hline 2022 & 78,388 & $19,832,209$ & $28,331.66$ & $106,486.98$ \\
\hline 2023 & 81,595 & $20,643,643$ & $29,490.76$ & $135,977.74$ \\
\hline 2024 & 84,835 & $21,463,138$ & $30,661.79$ & $166,639.53$ \\
\hline 2025 & 88,106 & $22,290,693$ & $31,844.03$ & $198,483.56$ \\
\hline 2026 & 91,408 & $23,126,310$ & $33,037.46$ & $231,521.02$ \\
\hline 2027 & 94,743 & $23,969,987$ & $34,242.83$ & $265,763.85$ \\
\hline 2028 & 98,110 & $24,821,724$ & $35,459.76$ & $301,223.61$ \\
\hline
\end{tabular}

Based on table 3, it can be seen that the landfill almost be full in 2022 so the government must have a plan to prepare new land and it is not easy to do. One of the effective solution for its problem is application of reducing, reusing, and recycling (3R) mechanism on waste management $[12,13]$. The solution is expected to reduce the waste that will be manage in the landfill so it can extend the lifetime of the landfill.

The composition of waste in Pati Regency consists of $65.28 \%$ organic waste; $8.07 \%$ paper; plastic $15.66 \%$; metal $0.79 \% ; 0.79 \%$ rubber; fabric / textile $2.65 \%$; wood $1.11 \%$; glass 0.91 ; others 3.09 ; and B3 $1.66 \%$ [9]. Organic waste dominates the composition waste in Pati Regency so it needs to be processed before entering the landfill. Organic waste has the potential to be processed into compost. The composting process can reduce 50$85 \%$ of the volume of waste [13]. The amount of waste generation in landfills will decrease by processing organic waste to compost/ fertilizer, it will impact to extend landfill lifetime significantly [14]. Meanwhile the percentage of inorganic waste composition in Pati Regency is $34.72 \%$, where plastic waste has the highest percentage and provides opportunity for recycling. According to the previous research the economic benefits of recycling activities averaged Rp. 2,000,- per $\mathrm{kg}$ of inorganic waste and provide employment opportunities to an average of 9 scavengers per waste management site with an average income of $\mathrm{Rp}$. $1,300,000,-$ per month [15]. Processing inorganic waste through recycling not only extending the lifetime of landfill but also providing economic benefits to the community.

According to Indonesia's Agenda 21 report, the National Strategy for Sustainable Development that the opportunity for waste management for composting 30$40 \%$ and recycling of waste (inorganic) reaches $15-25 \%$. In the fact that the participation of community in Pati regency to manage their waste from the sources is still low so in this study used the minimum target of the National Strategy for Sustainable Development to be applied in Pati Regency. In this study a scenario of reducing $30 \%$ of organic waste every year and $15 \%$ of annual inorganic waste is recycled every year can be seen ini table 4.

Based on table 4 it can be seen that composting and recycling inorganic waste can reduce waste generation from $35,802,927 \mathrm{~kg}$ to $19,691,610 \mathrm{~kg}$ in 2028 so it will have an impact also on decreasing Sukoharjo landfill load.

Table 4. Waste generation in 2019-2028 after reduction by 3R mechanism

\begin{tabular}{|c|c|c|c|c|c|c|}
\hline \multirow{2}{*}{ Year } & \multicolumn{2}{|c|}{ Waste Generation } & \multirow{2}{*}{$\begin{array}{c}\text { Composting } \\
(\mathbf{K g})\end{array}$} & \multirow{2}{*}{$\begin{array}{l}\text { Anorganic } \\
\text { waste } \\
\text { recycling } \\
(\mathrm{Kg})\end{array}$} & \multirow{2}{*}{$\begin{array}{c}\text { Total of } \\
\text { reduction } \\
(\mathrm{Kg})\end{array}$} & \multirow{2}{*}{$\begin{array}{c}\text { Waste } \\
\text { Generation after } \\
\text { reduction }(\mathrm{Kg})\end{array}$} \\
\hline & Vol. $\left(\mathbf{m}^{3}\right)$ & Weight (Kg) & & & & \\
\hline 2019 & 134,345 & $33,989,271$ & $10,196,781$ & $5,098,391$ & $15,295,172$ & $18,694,099$ \\
\hline 2020 & 135,141 & $34,190,788$ & $10,257,236$ & $5,128,618$ & $15,385,855$ & $18,804,933$ \\
\hline 2021 & 135,938 & $34,392,305$ & $10,317,692$ & $5,158,846$ & $15,476,537$ & $18,915,768$ \\
\hline 2022 & 136,734 & $34,593,823$ & $10,378,147$ & $5,189,073$ & $15,567,220$ & $19,026,603$ \\
\hline
\end{tabular}




\begin{tabular}{|l|l|l|l|l|l|l|}
\hline 2023 & 137,531 & $34,795,340$ & $10,438,602$ & $5,219,301$ & $15,657,903$ & $19,137,437$ \\
\hline 2024 & 138,328 & $34,996,858$ & $10,499,057$ & $5,249,529$ & $15,748,586$ & $19,248,272$ \\
\hline 2025 & 139,124 & $35,198,375$ & $10,559,513$ & $5,279,756$ & $15,839,269$ & $19,359,106$ \\
\hline 2026 & 139,921 & $35,399,892$ & $10,619,968$ & $5,309,984$ & $15,929,952$ & $19,469,941$ \\
\hline 2027 & 140,717 & $35,601,410$ & $10,680,423$ & $5,340,211$ & $16,020,634$ & $19,580,775$ \\
\hline 2028 & 141,514 & $35,802,927$ & $10,740,878$ & $5,370,439$ & $16,111,317$ & $19,691,610$ \\
\hline
\end{tabular}

The waste generation in Sukoharjo landfill after reduction through $3 \mathrm{R}$ mechanism can be seen on table 5 . It will be known the lifetime of the landfill when waste is handled before entering the landfill. Composting and recycling inorganic waste can be done at the source by the community through biopore, composter, TPS 3R, TPS, trash bank, compost house and also in landfill [1618]. But if composting and recycling activities is done by landfill, it will require large area for composting and recycling facilities. Meanwhile if composting is done at the sources, not only extend the lifetime of landfills, but also saves transportation of garbage truck from sources or temporary storage waste to the landfill. To increase the percentage of recycling, cooperation is needed between the formal and informal sectors in the process of recycling waste [19]. Recycling activities by the informal sector contribute to saving raw material resources, reducing land requirements for landfill, saving energy in producing various consumption products, and absorbing labor in the waste recycling industry [13].

Based on table 5 it can be seen that accumulation volume of compacted waste in Sukoharjo landfill through $3 \mathrm{R}$ mechanism is $109,168 \mathrm{~m}^{3}$ in 2025 . It means that the landfill will be almost full in 2025. If it is compared with accumulation volume of compacted waste without $3 \mathrm{R}$ mechanism there is extend of landfill lifetime from 2022 to 2025 .

Table 5. Waste generation in Sukoharjo Landfill 2019-2028 with 3R mechanism

\begin{tabular}{|c|c|c|c|c|c|c|}
\hline \multirow{2}{*}{ Year } & \multirow{2}{*}{$\begin{array}{c}\text { Waste } \\
\text { Generation } \\
\text { after } \\
\text { reduction } \\
(\mathrm{Kg})\end{array}$} & \multirow{2}{*}{$\begin{array}{c}\text { Percentage } \\
\text { of waste } \\
\text { services } \\
(\%)\end{array}$} & \multicolumn{2}{|c|}{$\begin{array}{c}\text { Waste Generation in } \\
\text { Landfill (Kg) }\end{array}$} & \multirow{2}{*}{$\begin{array}{l}\text { Volume of } \\
\text { compacted } \\
\text { waste }\left(\mathbf{m}^{3}\right)\end{array}$} & \multirow{2}{*}{$\begin{array}{c}\text { Accumulation } \\
\text { Volume of } \\
\text { compacted } \\
\text { waste }\left(\mathbf{m}^{3}\right)\end{array}$} \\
\hline & & & $\begin{array}{c}\text { Weight } \\
\text { (Kg) }\end{array}$ & $\begin{array}{c}\text { Volume } \\
\qquad\left(\mathbf{m}^{3}\right)\end{array}$ & & \\
\hline 2019 & $18,694,099$ & 51.33 & $9,595,047$ & 37,928 & 13,708 & 13,708 \\
\hline 2020 & $18,804,933$ & 53.33 & $10,067,792$ & 39,639 & 14,327 & 28,035 \\
\hline 2021 & $18,915,768$ & 55.33 & $10,588,572$ & 41,368 & 14,952 & 42,986 \\
\hline 2022 & $19,026,603$ & 57.33 & $11,115,238$ & 43,114 & 15,583 & 58,569 \\
\hline 2023 & $19,137,437$ & 59.33 & $11,647,843$ & 44,878 & 16,220 & 74,789 \\
\hline 2024 & $19,248,272$ & 61.33 & $12,186,439$ & 46,660 & 16,864 & 91,654 \\
\hline 2025 & $19,359,106$ & 63.33 & $12,731,079$ & 48,459 & 17,514 & 109,168 \\
\hline 2026 & $19,469,941$ & 65.33 & $13,281,816$ & 50,276 & 18,171 & 127,339 \\
\hline 2027 & $19,580,775$ & 67.33 & $13,838,704$ & 52,110 & 18,834 & 146,173 \\
\hline 2028 & $19,691,610$ & 69.33 & $14,401,796$ & 53,961 & 19,503 & 165,676 \\
\hline
\end{tabular}

\section{Conclusion}

The increase in waste generation and percentage of waste service results in an increase of waste generation in the landfill. In 2019 the waste generation in Sukoharjo landfill is $68,958 \mathrm{~m}^{3}$ and increases to $98,110 \mathrm{~m}^{3}$ in 2028 . Based on the calculation, Sukoharjo landfill will be full in 2022. There is Reduce, Reuse, Recycle (3R) process through composting and recycling inorganic waste can reduce waste generation in the landfill and extend the lifetime of the Sukoharjo landfill until 2025.

The reduction in Sukoharjo landfill load can be achieved when the $3 \mathrm{R}$ process in organic and inorganic waste can be implemented properly in Pati Regency. The application of the $3 \mathrm{R}$ process can reduce the volume of waste generation in the landfill and extend the lifetime of the landfill.

\section{References}

1. Statistics of Pati Regency, Pati Regency in Figure 2018, Pati, Indonesia (2018)

2. Department of Environment Pati Regency, Monthly Periodic Report on Daily Waste Volume for 2017, Pati, Indonesia (2018)

3. P. Setyono, The Horizon of Understanding the Environment, Surakarta: Sebelas Maret University Press (2015)

4. Ministry of Environment, Waste Management act No. 18/2008, Jakarta, Indonesia (2008)

5. R. Joshi, S. Ahmed, Status and challenges of municipal solid waste management in India: A review, Cogent Environ. Sci. 2(1), 1-18 (2016)

6. A. Luthfi, K. Elly, Community Participation in Waste Management System in Sukoharjo Landfill, Pati Regency, Abdimas 17(1), 13-20 (2013)

7. R. Yustikarini, P. Setyono, Wiryanto, An Evaluation and Study of Trash Treatment in Reducing Loading 
of Solid Waste Processing Plant at Milangasri Landfill, Magetan Regency, Proceeding Biol. Educ. Conf. 14(1), 177-185 (2017)

8. Alhderi, N.A. Ahmed, Purwanto, Sunoko, Henna Rya, Impacts of Four Seasons In Municipal Solid Waste In Al-Khums City, Science Journal of Environmental Engineering Research, 1-5 (2015)

9. T. Akyen, C.B. Boye, Y.Y. Ziggah, Landfill Lifespan Estimation: A Case Study, Ghana Min. J. 17(2), 1-5 (2017)

10. Ministry of Public Work, Final Report Facilitating Waste Management and Technical Planning (PTMP) and Detailed Technical Plan (RTR) for Pati Regency Waste Management System (2016)

11. G. Tchobanoglous, H. Theisen, S. Vigil, Integrated Solid Waste Management, Engineering Principles and Management Issues, Kogakusha, Ltd: Mc. Graw Hill (1993)

12. A. Minelgaite, G. Liobikiene, Waste problem in European Union and its influence on waste management behaviours, Sci. Total Environ. 667, 86-93 (2019)

13. Luong, N. Duc, Giang, H. Minh, Thanh, B. Xuan, $\mathrm{N}$. Hung, Challenges for municipal solid waste management practices in Vietnam, Waste Technol. 1(1),17-21 (2013)

14. Thanha, H. Trung, Yabar, Helmut, H. Yoshiro, Analysis of the environmental benefits of introducing municipal organic waste recovery in Hanoi city, Vietnam, Procedia Encironmental Sciences 28, 185-194 (2015)

15. K. Istiqomah, S. Rahayu, W. Ekawanti, Analysis of the Economic Value of Waste in Waste Management Sites (An Empirical Study on Sanitation Offices of the Administrative City of South Jakarta), Pros. Semin. Nas. multidisiplin ilmu (2011)

16. Firmansyah, Adi, Aisyah, W.N. Fatimah, Mubarokah, Ulfah, 'Innovation of Garbage Management Based on Community, Pros. Semin. Nas. Hasil-Hasil PPM IPB, ISBN 978-602-8853-293 (2016)

17. Baba, S.J. Othma, Purwanto, Sunoko, H. Rya, Evaluation of Municipal Solid Waste Management System, Science Journal of Environmental Engineering Research, ISSN 2276-7495 (2015)

18. A. Sinaga, E. Sutrisno, Budisulistiorini, S. Hapsari, Composting Planning As An Alternative Organic Waste Processing (Case Study: Putri Cempo Landfill, Mojosongo), Jurnal Presipitasi 7(1) (2010)

19. A. Febrino, B. Rahardyan, The Effect of Formal Sector and Informal Sector Integration on Processing and Utilization of Waste in Temporary Shelter, J. Tek. Lingkung. 21(1), 29-38 (2015) 